\title{
Antibiotic Complex SP-351 Produced by a Psychrophile, Streptomyces sp. No. $351^{\dagger}$
}

\author{
Noboru Yoshida, Yukio HachiYa, Kozo Ueda, ${ }^{*}$ Yoshiki Tani \\ and Koichi Ogata
}

Department of Agricultural Chemistry, Kyoto University, Kyoto, Japan

*Central Research Institute, Kuraray Co., Ltd., Kurashiki-shi, Japan

Received October 16, 1972

\begin{abstract}
In the course of a screening study for antibiotics using psychrophilic microorganisms a water-insoluble antibiotic complex, SP-351, was found in the culture filtrate of a psychrophilic actinomycete, strain No. 351. This active principle was isolated and characterized as a cyclicpolylactone antibiotic. The SP-351-producing strain was classified as a facultative psychrophile and identified as Streptomyces phaeochromogenes.

The main components of the antibiotic complex SP-351 changed with the composition of the culture medium but not with culture temperatures. Component A was exclusively produced in a medium composed of roasted soybean powder and glycerol; components $B$ and $\mathrm{C}$ in a medium composed of soybean, glycerol and potassium nitrate; and components $\mathrm{A}$ and $\mathrm{D}$ in a synthetic medium containing a hydrocarbon, alcohol or ester as the sole carbon source. Maximum production of SP-351 from $n$-paraffin and methyl acetate was 10 and 15 $\mathrm{mcg} / \mathrm{ml}$, respectively.

SP-351 showed strong antibacterial activity against Gram-positive bacteria and acidfast bacteria at $0.1 \sim 0.3 \mathrm{mcg} / \mathrm{ml}$ concentrations.
\end{abstract}

In a previous paper, ${ }^{1)}$ the isolation of a psychrophilic Streptomyces sp. No. 81, and its antibiotic production at low temperatures were described. Further investigation has revealed that this organism is a new species of Streptomyces which was identified as Streptomyces griseus subsp. psychrophilus Yoshida, Tani and Ogata, ${ }^{2)}$ and that the antibiotics produced by this organism at low and moderate temperatures, respectively, are new peptide antibiotics, which we named cryomycin ${ }^{2}$ and M-81. ${ }^{3 \prime}$

During a screening study for antibiotics using psychrophilic microorganisms, another Streptomyces strain, No. 351, was found to produce a water-insoluble antibiotic complex to the same degree, at both low and moderate temperatures. This organism is characterized as a psychrophile due to its more abundant

$\dagger$ Studies on Antibiotics Produced by Psychrophilic Microorganisms. Part II. Part of this work was presented at the meeting of the Kansai Division of the Agricultural Chemical Society of Japan held in Kyoto, February 19, 1972. growth at low temperatures than at moderate ones.

The antibiotic complex SP-351 produced by strain No. 351 was separated into the four active components $\mathrm{A}, \mathrm{B}, \mathrm{C}$ and $\mathrm{D}$ on a silicic acid thin-layer chromatogram. The main components of this antibiotic are altered by cultivation conditions, especially by the culture medium used.

Strain No. 351 as well as Streptomyces griseus subsp. psychrophilus assimilated alcohols, esters and $n$-paraffins as the sole carbon source and produced its own antibiotics. ${ }^{4}$ ? The antibiotic produced from these carbon sources by strain No. 351 contained components $A$ and $D$.

The properties of strain No. 351 and the isolation and characterization of the antibiotic complex SP-351, as well as its biological activity, are reported in this publication.

\section{MATERIALS AND METHODS}

1) Media for production of antibiotic complex 
$S P-351$. The following three media were used to produce the antibiotic.

a) A medium composed of roasted soybean powder (kinako in Japanese) $20 \mathrm{~g}$; glycerol $20 \mathrm{~g}$; yeast extract $2 \mathrm{~g} ; \mathrm{KH}_{2} \mathrm{PO}_{4} 2 \mathrm{~g} ; \mathrm{NaCl} 2 \mathrm{~g}$ and $\mathrm{MgSO}_{4} \cdot 7 \mathrm{H}_{2} \mathrm{O} 0.1 \mathrm{~g}$ in $1000 \mathrm{ml}$ of tap water at $\mathrm{pH} 6.0$, was used to produce mainly SP-351 A.

b) A medium composed of soybean (dried or raw) $20 \mathrm{~g}$; glycerol $20 \mathrm{~g}$; yeast extract $2 \mathrm{~g}$; $\mathrm{K}_{2} \mathrm{HPO}_{4} 0.5 \mathrm{~g}$; $\mathrm{NaCl} 2 \mathrm{~g} ; \mathrm{MgSO}_{4} \cdot 7 \mathrm{H}_{2} \mathrm{O} 0.1 \mathrm{~g}$ and $\mathrm{KNO}_{3} 2 \mathrm{~g}$ in $1000 \mathrm{ml}$ of tap water at pH 7.0, was used to produce mainly SP-351 B and C. Soybean was independently extracted by boiling and freed from the broth before being mixed with other components.

c) To produce SP-351 from hydrocarbons etc., a medium composed of the carbon source of $30 \mathrm{ml}$; $\left(\mathrm{NH}_{4}\right)_{2} \mathrm{SO}_{4} 5 \mathrm{~g} ; \mathrm{K}_{2} \mathrm{HPO}_{4} 2 \mathrm{~g} ; \mathrm{KH}_{2} \mathrm{PO}_{4} 1 \mathrm{~g} ; \mathrm{MgSO}_{4}$. $7 \mathrm{H}_{2} \mathrm{O} \quad 0.5 \mathrm{~g}$ and a vitamin solution of $60 \mathrm{ml}$ in a total volume of $1000 \mathrm{ml}$ at $\mathrm{pH} 7.0$, was used. The vitamin solution contained thiamine- $\mathrm{HCl} 8 \mathrm{mg}$; ribofravin $8 \mathrm{mg}$; nicotinic acid $16 \mathrm{mg}$; folic acid $160 \mu \mathrm{g}$; biotin $64 \mu \mathrm{g}$; Ca-pantothenate $8 \mathrm{mg} ; p$-aminobenzoic acid $1.6 \mathrm{mg}$ and pyridoxol $250 \mu \mathrm{g}$ in a total of $1000 \mathrm{ml}$. As the sole carbon source; $n$-paraffins, methanol, ethanol, methyl acetate and ethyl acetate were employed.

2) Assay systems for the antibiotic complex SP-35I. The pulp disk method or agar dilution streak method using Micrococcus lysodeikticus IFO 3333 as the test organism was used to estimate the biological activity of SP-351. The purity of the antibiotic was assayed with thin-layer chromatography using chloroformethyl acetate $(1: 2)$ as the developer.

\section{RESULTS AND DISCUSSION}

More than half of the isolated psychrophiles possessing antibacterial activity at low temperatures showed the activity also at moderate temperatures. Of these, one actinomycete, strain No. 351, which showed antibacterial activity to the same degree at both low and moderate temperatures, was used in the following experiments.

Table I. Cultural. Properties of Strain No. 351

\begin{tabular}{|c|c|c|c|c|c|}
\hline Medium & Growth & $\begin{array}{c}\text { Aerial } \\
\text { mycelium }\end{array}$ & $\begin{array}{l}\text { Vegetative } \\
\text { mycelium }\end{array}$ & $\begin{array}{l}\text { Soluble } \\
\text { pigment }\end{array}$ & Remarks \\
\hline Gelatin stab & $\begin{array}{l}\text { good, } \\
\text { surface }\end{array}$ & pinkish white & & dark brown purple & $\begin{array}{l}\text { slow and complete } \\
\text { liquefaction }\end{array}$ \\
\hline $\begin{array}{l}\text { Glucose- } \\
\text { asparagine } \\
\text { agar }\end{array}$ & $\begin{array}{l}\text { good, } \\
\text { spreading }\end{array}$ & $\begin{array}{l}\text { greenish gray to } \\
\text { pinkish gray, } \\
\text { flocculent }\end{array}$ & brown & light purplish gray & \\
\hline $\begin{array}{l}\text { Bouillon } \\
\text { agar }\end{array}$ & good & pinkish white & brown & dull red & \\
\hline $\begin{array}{l}\text { Glucose } \\
\text { bouillon } \\
\text { agar }\end{array}$ & $\begin{array}{l}\text { abundant, } \\
\text { elevated }\end{array}$ & $\begin{array}{l}\text { white to greenish } \\
\text { gray, flocculent }\end{array}$ & & & \\
\hline Starch agar & $\begin{array}{l}\text { good, } \\
\text { spreading }\end{array}$ & $\begin{array}{l}\text { light grayish } \\
\text { green, lichenous, } \\
\text { alveolate }\end{array}$ & white & violet & \\
\hline $\begin{array}{l}\text { Yeast ext. } \\
\text { agar }\end{array}$ & abundant & $\begin{array}{l}\text { dull greenish } \\
\text { white, alveolate }\end{array}$ & $\begin{array}{l}\text { dark } \\
\text { brown }\end{array}$ & dark brown purple & \\
\hline Czapek agar & $\begin{array}{l}\text { moderate, } \\
\text { spreading }\end{array}$ & $\begin{array}{l}\text { pale green, } \\
\text { powdery }\end{array}$ & white & light brown & \\
\hline $\begin{array}{c}\text { Tyrosine } \\
\text { agar }\end{array}$ & scant & thin, colorless & gray & pale brown & \\
\hline Milk & $\begin{array}{l}\text { ring } \\
\text { formation } \\
\text { on surface }\end{array}$ & pinkish gray & & & $\begin{array}{l}\text { alkaline, rapid } \\
\text { peptonization }\end{array}$ \\
\hline Potato plug & abundant & $\begin{array}{l}\text { light purplish } \\
\text { gray }\end{array}$ & $\begin{array}{l}\text { pinkish } \\
\text { gray }\end{array}$ & black & \\
\hline
\end{tabular}

No growth occurred on Carrot plug. 
Taxonomical studies on the isolated actinomycete, strain No. 351

Morphological and cultural properties. Vegetative mycelia of this strain developed well on most of the media used (Table I). On various media, it formed abundant aerial mycelia of about $1 \mu$ wide, which developed into many straight or flexing branches but did not form whorls nor spirals. On an electronmicroscopic observation, spore surfaces of this strain were smooth (Fig. 1). Soluble purple pigments were produced in both natural and synthetic media.

Physiological properties. Physiological properties of the strain are summarized in Table II. The organism utilized most of the car-

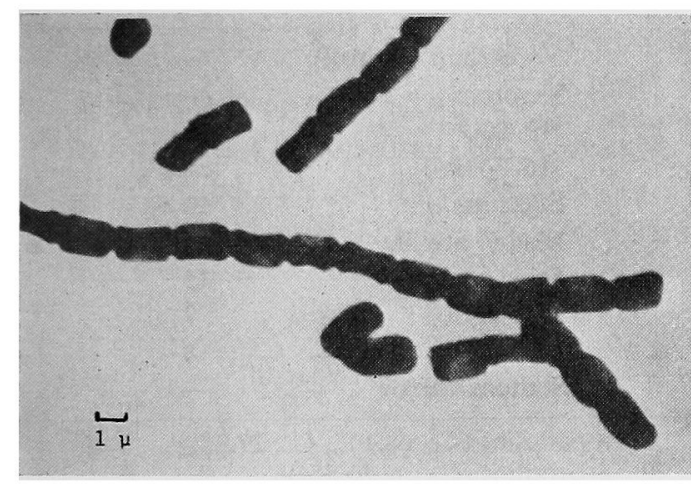

FIG. 1. Electron Micrograph of Strain No. 351. $(\times 2,500)$

Table II. Physiological Properties of Strain No. 351

Gelatin liquefaction Action on milk

$\mathrm{H}_{2} \mathrm{~S}$ formation Indole formation

$\mathrm{NH}_{3}$ formation

Nitrate reduction

Cellulolytic activity

Starch hydrolysis

Catalase

Urease

Tyrosinase

Assimilation of citrate

Optimum temperature positive alkaline, ring formation, rapid peptonization negative negative positive positive positive (weak) good present present present positive $25^{\circ} \mathrm{C}$

(No growth occurs above $35^{\circ} \mathrm{C}$ ) bohydrates tested except sodium acetate and sorbitol. Cellulolytic activity was weak.

Growth temperature. As shown in Fig. 2, the strain grew between $5^{\circ} \mathrm{C}$ and $32^{\circ} \mathrm{C}$. The maximum cell yield was obtained at $12^{\circ} \mathrm{C}$, while the most rapid growth was observed near $25^{\circ} \mathrm{C}$. No growth occurred above $35^{\circ} \mathrm{C}$. These characteristics provide additional evidence that strain No. 351 should be classified as a psychrophilic microorganism.

From these results, we concluded that this strain belongs to the genus Streptomyces, based on the description in Bergey's Manual, 7th ed. ${ }^{5}$ Comparative studies among the known species in this genus suggest that the tested strain is closely related to Streptomyces phaeochromogenes Waksman and Henrici, 1948. However, all the strains of $S$. phaeochromogenes from AKU* type culture collections could not grow well at low temperatures; their maximum cell yield was observed at moderate temperatures. Thus, we identified strain No. 351 as Streptomyces phaeochromogenes AKU 2882.

Effect of temperature on growth and antibiotic production

The temperature range, in which strain No. 351 could grow and produce the antibiotic, was investigated by culturing the organism at various temperatures (Fig. 2). The velocities of growth and antibiotic production accelerated with increased temperature. Almost the same maximum production of antibiotic was observed between $15^{\circ} \mathrm{C}$ and $28^{\circ} \mathrm{C}$. Maximum antibiotic production was reached after cultivation at $15^{\circ} \mathrm{C}$ for 5 days, and at $20 \sim 28^{\circ} \mathrm{C}$ for 4 days.

Effect of the culture medium on antibiotic production

As shown in Fig. 3, the antibiotic complex SP-351 produced by strain No. 351 separated into the four components on a silicic acid

* AKU: Abbreviation for Culture Collections, Faculty of Agriculture, Kyoto University, Kyoto, Japan. 


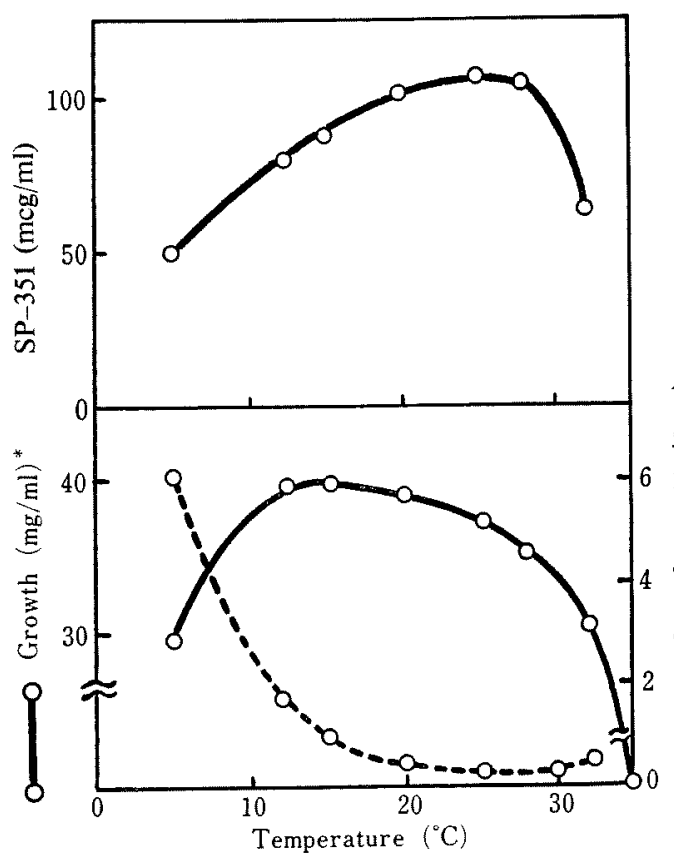

FIG. 2. Effect of Temperature on Growth and Antibiotic Production of Strain No. 351 in Medium (b).

* The growth is designated as a mycelial dry weight.

** The growth rate is designated as the period necessary for strain No. 351 to achieve a half maximum growth.

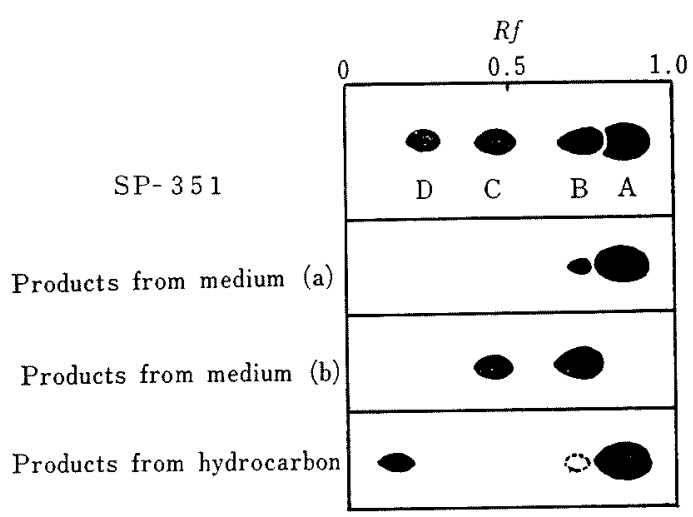

FIG. 3. Thin-layer Chromatogram of Antibiotic SP-351.

Solvent: Chloroform-ethyl acetate $(1: 2)$.

Detection: $20 \% \mathrm{H}_{2} \mathrm{SO}_{4}$

thin-layer chromatogram. We observed that the main components changed with the culture medium but not with the culturing temperature. The medium (a) composed of roasted soybean powder and glycerol induced the production of component $\mathrm{A}$, and the medium (b) composed of soybean, glycerol and potassium nitrate induced the production of components $\mathrm{B}$ and $\mathrm{C}$.

The product from non-sugar carbon sources was a mixture of two components. One was component $\mathrm{A}$ and the other was the substance which closely resembled component $\mathrm{D}$. The most utilizable carbon sources were methyl acetate and ethyl acetate (Table III).

TABle III. Production OF SP-351 from

Various Non-sugar Carbon Sources by Strain No. 351

Cultivation was carried out at $28^{\circ} \mathrm{C}$ for 4 days.

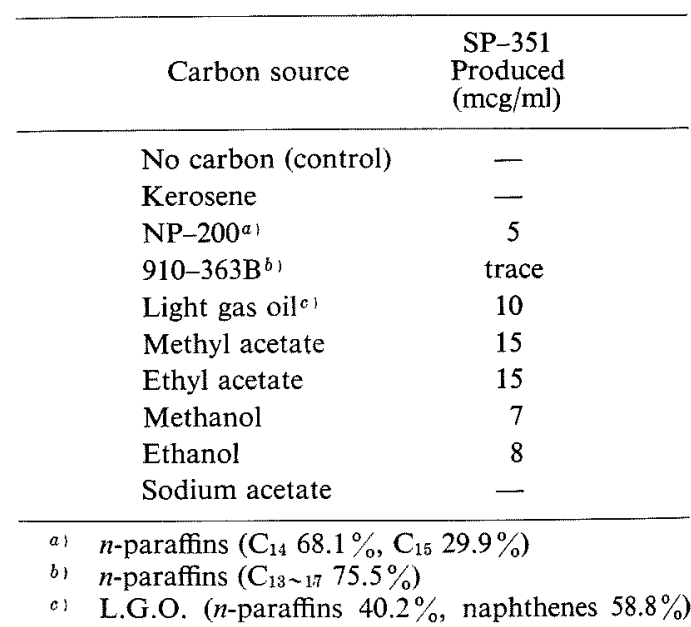

\section{Isolation of the antibiotic}

The antibiotic was produced in the culture broth but not in the mycelia. After removal of the mycelia by centrifugation, the culture filtrate was mixed with a half volume of ethyl acetate. Then the organic phase was separated from aqueous one and condensed in vacuo to dryness. Dried matter was extracted with a small volume of petroleum ether, and the petroleum ether-soluble fraction was subjected to silicic acid column chromatography, followed by elution with a mixed solvent of benzene and ethyl acetate $(6: 4)$. The active fractions were collected, decolorized with charcoal and condensed in vacuo to a small volume. The condensed solution was allowed to stand overnight in a refrigerator to give 
Table IV. Physicochemical Properties of the Antibiotic Complex, SP-351

\begin{tabular}{|c|c|c|c|c|c|c|}
\hline \multirow[b]{2}{*}{ Properties } & \multicolumn{4}{|c|}{ SP-351 } & \multirow{2}{*}{$\begin{array}{c}\text { Nonactin } \\
\text { (Corbaz et al.) }\end{array}$} & \multirow{2}{*}{$\begin{array}{c}\text { Monactin } \\
\text { (Beck et al.) }\end{array}$} \\
\hline & A & B & $\mathrm{C}$ & D & & \\
\hline Melting point & $145^{\circ} \sim 146^{\circ} \mathrm{C}$ & $62^{\circ} \sim 63^{\circ} \mathrm{C}$ & $66^{\circ} \sim 67^{\circ} \mathrm{C}$ & $68^{\circ} \mathrm{C}$ & $148^{\circ} \mathrm{C}$ & $63^{\circ} \sim 64^{\circ} \mathrm{C}$ \\
\hline \multirow{3}{*}{$\begin{array}{r}\text { Elemental } \\
\text { analysis }\end{array}$} & C 65.42 & C 65.82 & & & C 65.13 & C 65.58 \\
\hline & H 8.75 & H 9.12 & & & H 8.81 & H 8.85 \\
\hline & O 25.83 & O 25.05 & & & O 26.20 & O 25.56 \\
\hline $\begin{array}{c}\text { Molecular } \\
\text { weight }\end{array}$ & $\begin{array}{c}736 \\
\text { (Mass) }\end{array}$ & $\begin{array}{c}750 \\
\text { (Mass) }\end{array}$ & $\begin{array}{c}764 \\
\text { (Mass) }\end{array}$ & $\begin{array}{c}778 \\
\text { (Mass) }\end{array}$ & 737 & 752 \\
\hline Formula & & & & & \multirow{3}{*}{$\begin{array}{c}\mathrm{C}_{40} \mathrm{H}_{64} \mathrm{O}_{12} \\
0.62 \\
\text { end abs. } \\
\text { insol.in } \mathrm{H}_{2} \mathrm{O}\end{array}$} & \multirow{3}{*}{$\begin{array}{c}\mathrm{C}_{41} \mathrm{H}_{66} \mathrm{O}_{12} \\
0.48 \\
\text { end abs. } \\
\text { insol. in } \mathrm{H}_{2} \mathrm{O}\end{array}$} \\
\hline$R f$ value $^{a)}$ & 0.88 & 0.75 & 0.46 & 0.25 & & \\
\hline $\begin{array}{l}\text { UV max } \\
\text { Nature } \\
\text { IR }\end{array}$ & neutral & $\begin{array}{r}\text { end abso } \\
\text { colorless need } \\
\text { the same s }\end{array}$ & $\begin{array}{l}\text { rption } \\
\text { les, insol. in } \\
\text { ectrum }\end{array}$ & & & \\
\hline
\end{tabular}

a) Developer: $\mathrm{CHCl}_{3}$-EtOAc $(1: 2)$

crude crystals of antibiotic SP-351. Recrystallization from $n$-hexane gave colorless needles.

Physicochemical properties of SP-35I

Physicochemical properties of antibiotic $\mathrm{SP}-351$ are listed in Table IV. The amounts of components $\mathrm{C}$ and $\mathrm{D}$ isolated were too

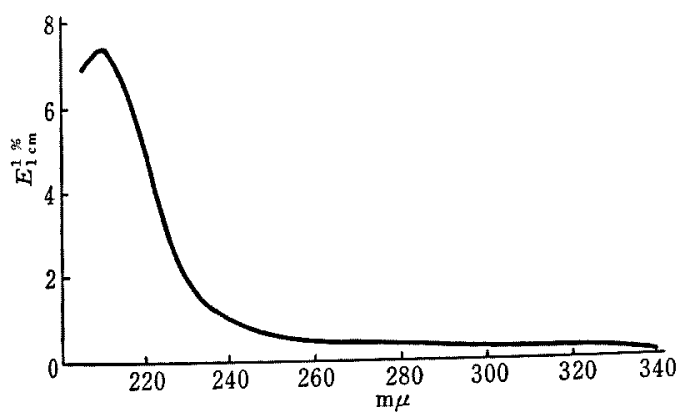

FIG. 4. Ultraviolet Absorption Spectrum of Antibiotic SP-351. small to use for elemental analysis. All components of SP-351 are neutral, colorless needles, and are insoluble in water. The ultraviolet and infrared absorption spectra of all components were the same (Figs. 4 and 5). Almost the same NMR spectra were obtained for SP-351 A and B (Figs. 6 and 7). From these characteristics, SP-351 was assumed to be a cyclicpolylactone antibiotic. From

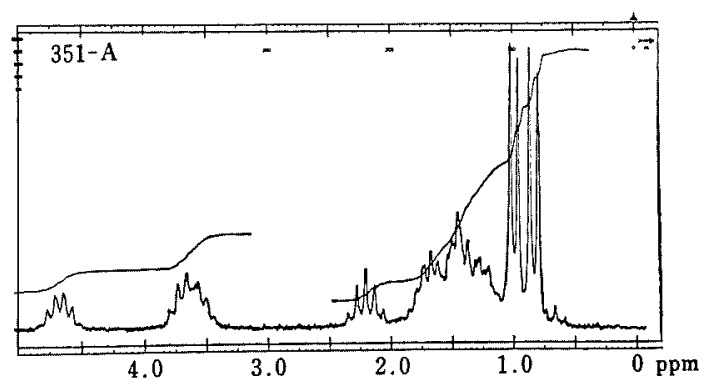

FIG. 6. NMR Spectrum of SP-351 A in $\mathrm{CCl}_{4} \mathrm{Solu}-$ tion with TMS as Internal Reference.

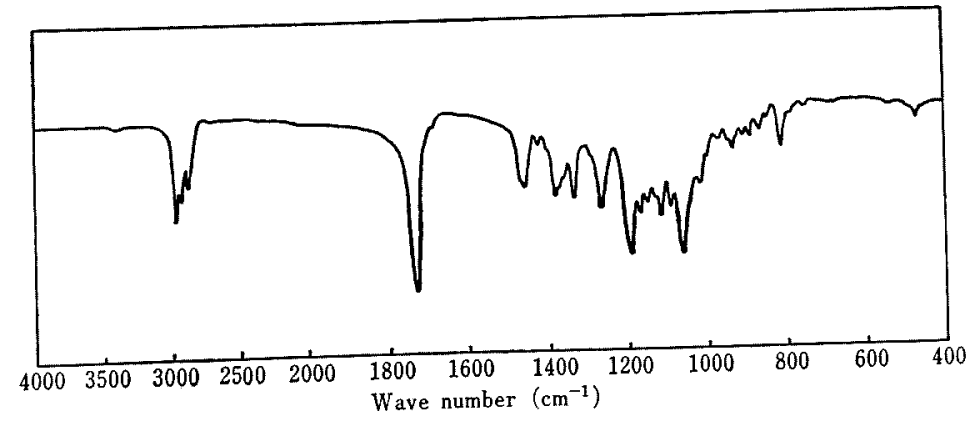

FIG. 5. Infrared Spectrum of SP-351 in $\mathrm{KBr}$ Tablet. 


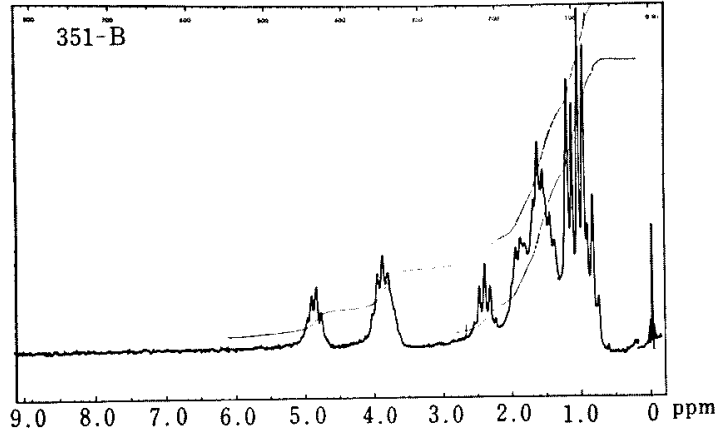

FIG. 7. NMR Spectrum of SP-351 B in $\mathrm{CCl}_{4}$ Solution with TMS as Internal Reference.

comparative studies with known substances, SP-351 A was found to be quite similar to nonactin $^{6}$ and lustericin. ${ }^{7}$ However, lustericin has a melting point at $130^{\circ} \mathrm{C}$, and its

Table V. Antimicrobial Spectrum OF SP-351

\begin{tabular}{|c|c|}
\hline Microorganism & $\underset{(\mathrm{mcg} / \mathrm{ml})}{\mathrm{M}) \mathrm{I.C}}$ \\
\hline Escherichia coli $\mathrm{K} 12$ IFO 3208 & -a) \\
\hline Aerobacter aerogenes IFO 3319 & - \\
\hline Serratia polymuthicum IFO 3055 & 0.2 \\
\hline Proteus vulgaris IFO 3045 & 一 \\
\hline Alcaligenes faecalis IFO 3160 & 0.2 \\
\hline Flavobacterium arborescens IAM 1100 & 0.2 \\
\hline Bacillus subtilis IFO 3037 & 0.8 \\
\hline Micrococcus lysodeikticus IFO 3333 & 0.1 \\
\hline Staphylococcus aureus IFO 3060 & 0.8 \\
\hline Sarcina lutea IFO 1099 & 0.2 \\
\hline Corynebacterium equi IAM 1038 & 0.8 \\
\hline Arthrobacter simplex IFO 3530 & 0.6 \\
\hline Brevibacterium ammoniagenes IFO 12071 & 0.2 \\
\hline Bacterium cadaveris IFO 3731 & - \\
\hline Pseudomonas aeruginosa IFO 3080 & - \\
\hline Streptococcus faecalis IFO 3181 & 0.3 \\
\hline Pediococcus hennevergi IFO 3884 & 0.3 \\
\hline Leuconostoc mesenteroides IFO 3426 & 0.3 \\
\hline Lactobacillus plantarum IFO 3070 & 0.3 \\
\hline Mycobacterium avium IFO 3154 & 1.5 \\
\hline Nocardia gardneri IFO 3385 & 1.5 \\
\hline Streptomyces albus AKU 2201 & 4.5 \\
\hline rimosus IFO 3226 & - \\
\hline griseus IFO 3430 & 一 \\
\hline griseus IFO 3237 & 2.2 \\
\hline griseus IFO 3357 & 3.5 \\
\hline fradiae IFO 3439 & 1.0 \\
\hline fradiae IFO 3123 & 1.0 \\
\hline antibioticus IFO 3117 & 4.5 \\
\hline
\end{tabular}

a) No inhibition was observed at $20 \mathrm{mcg} / \mathrm{ml}$ concentration. molecular weight is about 780. As shown in Table IV, SP-351 A and B are, respectively, quite similar to nonactin and monactin. ${ }^{\mathrm{g}}$

\section{Biological properties of $S P-351$}

The biological activity of SP-351 was studied with components $\mathrm{A}$ and $\mathrm{B}$. No difference between their activities was observed. As shown in Table V, SP-351 had a strong inhibitory activity against Gram-positive bacteria and some yeasts.

Table V. Antimicrobial Spectrum OF SP-351 (continued).

Microorganism $\begin{gathered}\text { M.I.C. } \\ (\mathrm{mcg} / \mathrm{ml})\end{gathered}$

Mucor mucedo IFO 5776

Rhizopus oryzae $\mathrm{M}-21$

Absidia lichteimi IFO 4009

Aspergillus oryzae M-61

Penicillium chrysogenum IFO 4626

Monascus purpureus IAM 8010

Neurospora crassa IFO 6068

Oospora viscosa IFO 4604

Fusarium lini IFO 5880

Gibberella fujikuroi IFO 5268

Ustilago zeae IFO 5346

Keratinomyces ajelloi IFO 7865

Sporotrichum schaenkii IFO 5983

Verticillium arbo-atrum IFO 5922

Isaria kogane IFO 5299

Gliocladium deliquescens IFO 6617

Phytophthora infestans IFO 4872

Trichophyton sulfureum IFO 5945

Saccharomyces cerevisiae AKU 4100

Eremascus fertilis IFO 0691

Endomyces hordei IFO 0104

Shizosaccharomyces pombe IFO 0346

Zygosaccharomyces soja IFO 0495

Pichia polymorpha IFO 0195

Hansenula anomala AKU 4300

Schwanniomyces occidentalis IFO 0371

Debaryomyces japonicus IFO 0039

Saccharomycodes ludwigii IFO 0339

Hanseniaspora valbyensis IFO 0115

Lipomyces lipoferus IFO 0673

Sporobolomyces salmonicolor IFO 0374

Torulopsis candida IFO 0768

Candida albicans IFO 0197

Trigonopsis variabilis IFO 0671

$-$

Torula rubra AKU 4730

1.6

Trichosporon cutaneum IFO 0174 


\section{CONCLUSION}

SP-351 possesses properties characteristic to cyclicpolylactone antibiotics such as lustericin, $\left.\mathrm{N}-329 \mathrm{~A},{ }^{9}\right)$ nonactin and monactin. However, SP-351 differs from all of these in its isolation procedure. Lustericin, N-329A, nonactin and its related compounds are extracted from mycelia but not from the culture broth, while SP-351 is extracted from the culture filtrate. Extraction of the mycelial cake of strain No. 351 with methanol or acetone produced no antibiotic.

Furthermore, SP-351 does not show antifungal activity against phytopathogenic fungi as does Piricularia oryzae and Helminthosporium sigmoideum. ${ }^{10}$ ) Other cyclicpolylactone antibiotics inhibit the growth of Piricularia oryzae at a concentration of $0.1 \sim 0.2 \mathrm{mcg} /$ $\mathrm{ml}$.

The minimum inhibitory concentration of lustericin or nonactin against Micrococcus sp. is $0.5 \mathrm{mcg} / \mathrm{ml}$, and that of $\mathrm{SP}-351$ is $0.1 \mathrm{mcg} /$ $\mathrm{ml}$.

The SP-351-producing organism differs from Streptomyces sp. $10400,{ }^{7,}$ the producer of lustericin and from Stm. tsushimaensis, ${ }^{91}$ Stm. SC $3763^{11)}$ and Stm. werraensis, ${ }^{12)}$ the producers of nonactin, in the following respects: 1) Strain No. 351 produces soluble purple pigments while the others produce none or brown soluble pigments. 2) Strain No. 351 is psychrophilic, whereas the others are mesophilic and show poor growth at low temperatures.

Strain No. 351 is notable for its good growth and antibiotic production at low temperatures as well as at moderate ones. And, it has the striking characteristics of assimilating nonsugar carbon sources, i.e. alcohols, esters, n-paraffins etc. to produce SP-351.

Based on these results and comparisons, SP-351 is seen as a new cyclicpolylactone antibiotic which closely resembles nonactin and its related compounds.

Acknowledgement. We express our deep thanks to Mr. K. Minami and Mr. M. Yamamura of the Maruzen Oil Co., Ltd. for their kind supply of NP-200, $910-363 \mathrm{~B}$ and light gas oil.

\section{REFERENCES}

1) K. Ogata, N. Yoshida, M. Ohsugi and Y. Tani, Agr. Biol. Chem., 35, 79 (1971).

2) N. Yoshida, Y. Tani and K. Ogata, J. Antibiot., 25, 653 (1972).

3) N. Yoshida, S. Hayashi, Y. Tani and K. Ogata, ibid., in press.

4) N. Yoshida, Y. Tani and K. Ogata, ibid., 25, 546 (1972).

5) R. S. Breed, E. G. D. Murray and N. R. Smith, "Bergey's Manual of Determinative Bacteriology," 7th ed., The Williams and Wilkins Co., 1957.

6) R. Corbaz, L. Ettlinger, E. Gäumann, W. KellerSchierlein, F. Kradolfer, L. Neipp, V. Prelog and H. Zähner, Helv. Chim. Acta, 38, 1445 (1955).

7) M. Shibata, K. Nakazawa and M. Inoue, Japan 18,445 ('60), Dec. 20.

8) J. Beck, H. Gerlach, V. Prelog and W. Voser, Helv. Chim. Acta, 45, 620 (1962).

9) H. Nishimura, M. Mayama, T. Kimura, A. Kimura, Y. Kawamura, K. Tawara, Y. Tanaka, S. Okamoto and H. Kyotani, J. Antibiotics, 17A, 11 (1964).

10) N. Yoshida et al., unpublished data.

11) E. Meyers, F.E. Pansy, D. Perlman, D. A. Smith and F. L. Weisenborn, J. Antibiotics, 18A, 128 (1965).

12) K. H. Wallhäusser, G. Huber, G. Nesemann, P. Präve and K. Zepf, Arzneimittel Forsch., 14, 356 (1964). 